\author{
Correspondence \\ Peter Kämpfer \\ peter.kaempfer@umwelt. \\ uni-giessen.de
}

\section{Paenochrobactrum gallinarii gen. nov., sp. nov., isolated from air of a duck barn, and reclassification of Pseudochrobactrum glaciei as Paenochrobactrum glaciei comb. nov.}

\author{
Peter Kämpfer, ${ }^{1}$ Elena Martin, ${ }^{2}$ Nicole Lodders, ${ }^{1}$ Udo Jäckel, ${ }^{2}$ \\ Birgit E. Huber, ${ }^{3}$ Peter Schumann, ${ }^{4}$ Stefan Langer, ${ }^{3}$ \\ Hans-Jürgen Busse ${ }^{3}$ and Holger Scholz ${ }^{5}$ \\ ${ }^{1}$ Institut für Angewandte Mikrobiologie, Justus-Liebig-Universität Giessen, D-35392 Giessen, Germany \\ ${ }^{2}$ Bundesanstalt für Arbeitschutz und Arbeitsmedizin, D-10317 Berlin, Germany \\ ${ }^{3}$ Institut für Bakteriologie, Mykologie und Hygiene, Veterinärmedizinische Universität, A-1210 Wien, \\ Austria \\ ${ }^{4}$ DSMZ - Deutsche Sammlung von Mikroorganismen und Zellkulturen, D-38124 Braunschweig, \\ Germany \\ ${ }^{5}$ Bundeswehr Institute of Microbiology, D-80937 Munich, Germany
}

A Gram-negative, rod-shaped, oxidase-positive, non-spore-forming, non-motile bacterium $\left(\mathrm{Sa} 25^{\mathrm{T}}\right)$ was isolated from air of a duck barn. 16S rRNA gene and recA sequence analyses clearly placed the isolate in the vicinity of the Brucella-Ochrobactrum-Pseudochrobactrum group, with the closest relative being Pseudochrobactrum glaciei KMM $3858^{\top}$. This allocation was confirmed by analyses of the quinone system (ubiquinone Q-10), fatty acid data (major fatty acids $\mathrm{C}_{18: 1} \omega 7 \mathrm{c}$ and $\mathrm{C}_{19: 0}$ cyclo $\omega 8 \mathrm{c}$ ) and polar lipid profile (major components diphosphatidylglycerol, phosphatidylmonomethylethanolamine, phosphatidylethanolamine, phosphatidylglycerol, phosphatidylcholine and unknown aminolipid AL1; moderate amounts of three unknown polar lipids, L1-L3, an unknown aminolipid and an unknown aminophospholipid APL2). The polyamine pattern of $\mathrm{Sa}^{2} 5^{\top}$ exhibited the major compound putrescine and moderate amounts of spermidine; a similar polyamine pattern with the major compound putrescine was also detected in Pseudochrobactrum glaciei KMM $3858^{\top}$. DNA-DNA hybridization of strain $\mathrm{Sa}^{2} 5^{\top}$ with Pseudochrobactrum glaciei KMM $3858^{\top}$ and the type strains of the other Pseudochrobactrum species showed values ranging from 50.3 to $24.8 \%$, and physiological and biochemical data clearly differentiated this isolate from the described Pseudochrobactrum species. Since Sa25 ${ }^{\top}$ and Pseudochrobactrum glaciei KMM $3858^{\top}$ form a distinct lineage in the $16 \mathrm{~S}$ rRNA gene sequence-based phylogenetic tree, and this separate position is supported by unique characteristics of their polyamine patterns and polar lipid profiles, we propose the novel genus Paenochrobactrum gen. nov., with the type species Paenochrobactrum gallinarii sp. nov. (type strain Sa25 ${ }^{\top}=$ CCUG $57736^{\top}=$ CCM $7656^{\top}$ ) and the reclassification of Pseudochrobactrum

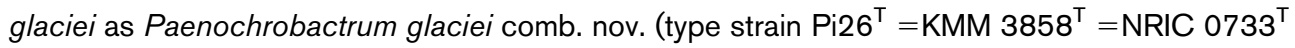
$=\mathrm{JCM} 15115^{\mathrm{T}}$ ).

\footnotetext{
The GenBank/EMBL/DDBJ accession numbers for the 16S rRNA gene sequence and partial recA sequence of strain $\mathrm{Sa}_{2} 5^{\top}$ are FN391023 and FM995366, respectively.

A recA sequence-based neighbour-joining tree, the total lipid profile of strain $\mathrm{Sa}_{2} 5^{\top}$ and a comparison of its fatty acid profile with those of related type strains are available as supplementary material with the online version of this paper.
}

The genus Pseudochrobactrum was proposed by Kämpfer et al. (2006). At present, it comprises the five species Pseudochrobactrum saccharolyticum, Pseudochrobactrum asaccharolyticum, Pseudochrobactrum kiredjianiae, Pseudochrobactrum lubricantis (Kämpfer et al., 2006, 2007a, 2009) and Pseudochrobactrum glaciei (Romanenko et al., 2008). The genus can be differentiated clearly from Ochrobactrum and Brucella on the basis of 16S rRNA gene and recA 
sequence data, as well as chemotaxonomic properties (Kämpfer et al., 2006, 2007a).

Strain Sa $25^{\mathrm{T}}$ was isolated from air collected in a duck barn in Germany on tryptone soy agar (TSA) at $25{ }^{\circ} \mathrm{C}$. The investigated barn accommodated 2500 ducks (each 14 months old). Bioaerosol samples were collected on gelatin filters by sampling $500 \mathrm{l}$ air at a rate of $301 \mathrm{~min}^{-1}$. Subsequently, filters were dissolved and decimally diluted in isotonic $\mathrm{NaCl}$ (up to $10^{-8}$ ). For cultivation, TSA plates were inoculated in triplicate with $0.1 \mathrm{ml}$ of each dilution. Strain Sa $25^{\mathrm{T}}$ was isolated from a plate inoculated with fluid from the first decimal dilution. The concentration of $S a 25^{\mathrm{T}}$ was approximately $2 \times 10^{3}$ c.f.u. per $\mathrm{m}^{3}$ air.

Subcultivation was done on TSA at $28{ }^{\circ} \mathrm{C}$ for $48 \mathrm{~h}$. On this agar, this organism grew at $15-45{ }^{\circ} \mathrm{C}$, but not at 10 or $50{ }^{\circ} \mathrm{C}$. Growth at $30{ }^{\circ} \mathrm{C}$ was also observed on MacConkey agar and R2A agar (all from Oxoid).

Gram-staining was performed as described by Gerhardt et al. (1994). Cell morphology was observed under a Zeiss light microscope at $\times 1000$, with cells grown for 3 days at $30{ }^{\circ} \mathrm{C}$ on nutrient agar. Isolation of DNA for estimation of the $\mathrm{G}+\mathrm{C}$ content was done according to Cashion et al. (1977) and the G+C content of the DNA was estimated according to Mesbah et al. (1989), resulting in a value of $49.7 \mathrm{~mol} \%$. The $16 \mathrm{~S}$ rRNA gene was analysed as described by Kämpfer et al. (2003). DNA extraction was carried out using the GenElute plant genomic DNA kit (SigmaAldrich) according to the manufacturer's instructions. The 16S rRNA gene was amplified by PCR using the primers 27F (5'-GAGTTTGATCMTGGCTCAG) and 1492R (5'-ACGGYTACCTTGTTACGACTT) (Lane, 1991) and the following cycling conditions: $95{ }^{\circ} \mathrm{C}$ for $3 \mathrm{~min}, 28$ cycles of $94{ }^{\circ} \mathrm{C}$ for $1 \mathrm{~min}, 57.3{ }^{\circ} \mathrm{C}$ for $45 \mathrm{~s}$ and $72{ }^{\circ} \mathrm{C}$ for $2 \mathrm{~min}$ and a final elongation step at $72{ }^{\circ} \mathrm{C}$ for $15 \mathrm{~min}$. The PCR product was purified with the QIAquick PCR purification kit (Qiagen) according to the manufacturer's instructions and sequenced with standard sequencing primers for the 16S rRNA gene. Phylogenetic analysis was performed using the ARB software package (December 2007 version; Ludwig et al., 2004) and the corresponding SILVA SSURef 95 database (July 2008 version; Pruesse et al., 2007). Trees were reconstructed using the maximumlikelihood method with fastDNAml (Olsen et al., 1994) and a $30 \%$ conservation filter (only alignment columns in which the frequency of the most abundant nucleotide is equal to or more than $30 \%$ are included in the calculation). Tree topology was further tested with a $50 \%$ filter and without filters. No significant differences could be detected between these trees regarding the grouping of strain $\mathrm{Sa} 25^{\mathrm{T}}$. Trees reconstructed with the neighbour-joining and maximum-parsimony methods using the software package MEGA version 4.0 (Tamura et al., 2007) showed similar results (not shown). The almostcomplete 16S rRNA gene sequence (1345 bp) of strain Sa25 $5^{\mathrm{T}}$ was compared by distance calculations (distance options according to the Kimura-2 model) using the software package MEGA version 4.0 (Tamura et al., 2007). A high similarity of $99.5 \%$ was found to Pseudochrobactrum glaciei KMM $3858^{\mathrm{T}}$. The sequence similarity to the type strains of three other Pseudochrobactrum species was $96.6 \%$ (Pseudochrobactrum saccharolyticum CCUG $33852^{\mathrm{T}}$ ), $96.5 \%$ (Pseudochrobactrum asaccharolyticum CCUG $46016^{\mathrm{T}}$ ) and 96.7\% (Pseudochrobactrum kiredjianiae CCUG $49584^{\mathrm{T}}$ ). A maximum-likelihood tree based on 16S rRNA gene sequences is shown in Fig. 1.

The partial $r e c A$ sequence of strain $\mathrm{Sa} 25^{\mathrm{T}}$ was amplified with degenerate primers $r e c A$-wob-f and $r e c A$-wob-r as described by Scholz et al. (2006), resulting in a 768 bp recA fragment that was compared to available $r e c A$ sequences in the EMBL nucleotide database. The highest sequence similarity (92.7\%) within 678 bp was found with Pseudochrobactrum glaciei KMM $3858^{\mathrm{T}}$, supporting the results of the $16 \mathrm{~S}$ rRNA gene sequence analysis. A neighbour-joining tree based on partial $r e c A$ gene sequences is shown in Supplementary Fig. S1 (available in IJSEM Online). Markedly lower partial recA gene sequence similarities were detected in comparison with other Pseudochrobactrum species. The similarity in the recA sequence (within $678 \mathrm{nt}$ ) to Pseudochrobactrum kiredjianiae CCUG $49584^{\mathrm{T}}$, Pseudochrobactrum saccharolyticum CCUG $33852^{\mathrm{T}}$ and Pseudochrobactrum asaccharolyticum CCUG $46016^{\mathrm{T}}$ was $85.3,84.2$ and $83.9 \%$, respectively.

Together with Pseudochrobactrum glaciei KMM $3858^{\mathrm{T}}$, strain $\mathrm{Sa} 25^{\mathrm{T}}$ formed a separate cluster in the phylogenetic tree of recA sequences apart from the other recognized Pseudochrobactrum species. Hence, both the 16S rRNA and recA gene sequence-based phylogenetic reconstructions support the separate position of Pseudochrobactrum glaciei KMM $3858^{\mathrm{T}}$ and strain $\mathrm{Sa} 25^{\mathrm{T}}$ in comparison to the other recognized Pseudochrobactrum species.

For polyamine, polar lipid and quinone analyses, cells were grown on PYE medium ( $0.3 \%$ peptone from casein, $0.3 \%$ yeast extract, $\mathrm{pH}$ 7.2). Quinones and polar lipids were extracted by an integrated protocol as described previously (Tindall 1990a, b; Altenburger et al., 1996); quinone composition was analysed by HPLC as reported by Stolz et al. (2007). Polyamines were extracted from biomass harvested at the late exponential growth phase and analysed as reported previously (Busse \& Auling, 1988; Busse et al., 1997; Stolz et al., 2007). The quinone system of strain $\mathrm{Sa} 25^{\mathrm{T}}$ consisted of the major compound ubiquinone Q-10 (98\%) and minor amounts of Q-8, Q-9 and Q-11 $(0.2-1.2 \%)$. The polar lipid profile of strain $\mathrm{Sa} 25^{\mathrm{T}}$ consisted of the major compounds phosphatidylethanolamine, phosphatidylglycerol, diphosphatidylglycerol, phosphatidylcholine, phosphatidylmonomethylethanolamine and unknown aminolipid AL1, moderate amounts of three unknown polar lipids, L1, L2 and L3, unknown aminolipid AL2 and an unknown aminophospholipid APL2 (Supplementary Fig. S2). In addition, an aminolipid that stretched over a long range in the first chromatographic dimension ('stretched aminolipid') was detected, which has not been reported to be present in the profile of 


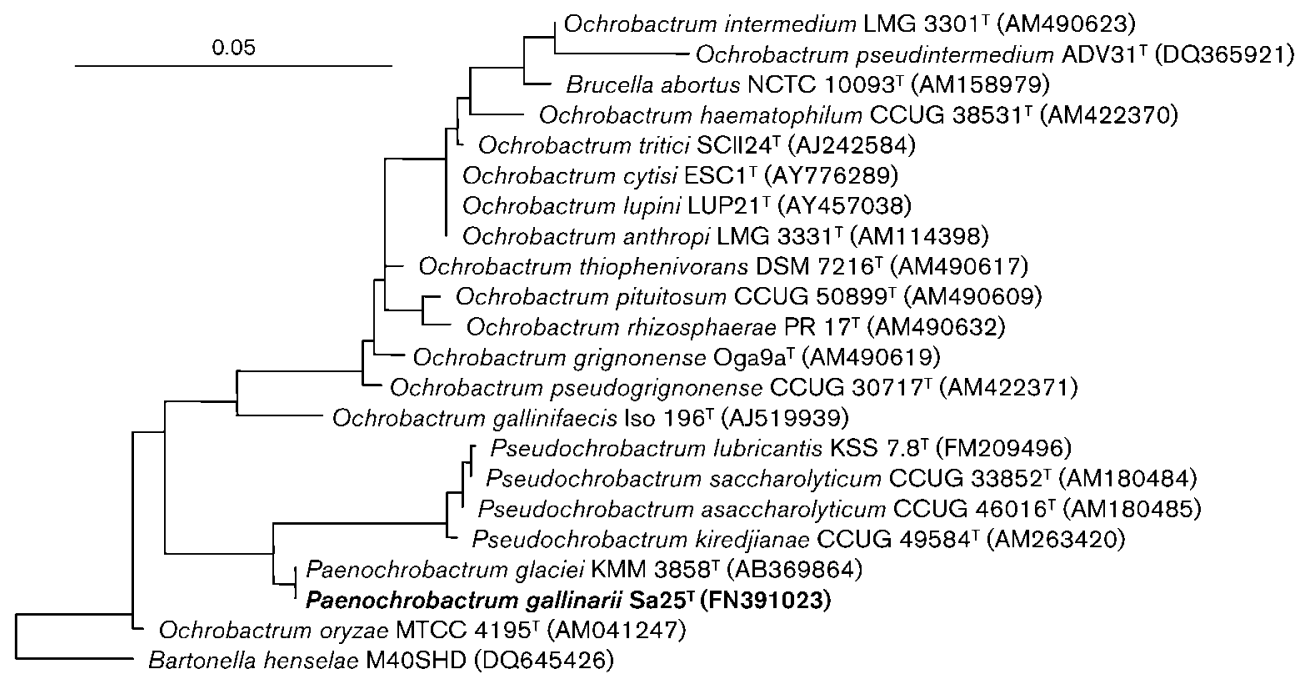

Fig. 1. Phylogenetic analysis based on $16 \mathrm{~S}$ rRNA gene sequences available from the EMBL database (accession numbers in parentheses). The phylogenetic tree was constructed using the ARB software package (December 2007 version; Ludwig et al., 2004) and the corresponding SILVA SSURef 95 database (July 2008 version; Pruesse et al., 2007). Tree building was performed using the maximum-likelihood method with fastDNAml (Olsen et al., 1994) and $30 \%$ conservation filter. Bar, 0.05 substitutions per nucleotide position.

any established Brucella, Ochrobactrum or Pseudochrobactrum species. Minor amounts of other lipids were also detected. The polar lipid profile of Pseudochrobactrum glaciei $\mathrm{KMM} 3858^{\mathrm{T}}$ shared the major characteristics, including the presence of the stretched aminolipid, but the unknown lipids AL2 and APL2 were not detectable. Furthermore, in the polar lipid profile of Pseudochrobactrum glaciei KMM $3858^{\mathrm{T}}$, another unidentified aminolipid was detected, which exhibited the same $R_{\mathrm{f}}$ value (i.e. the distance travelled by the analyte divided by the distance travelled by the solvent front) in the second dimension as AL1 but showed a slight smaller $R_{\mathrm{f}}$ in the first dimension (not shown). However, these data demonstrate that the polar lipid profile distinguishes $\mathrm{Sa} 25^{\mathrm{T}}$ and Pseudochrobactrum glaciei KMM $3858^{\mathrm{T}}$ from each other and both strains from all Brucella, Ochrobactrum and Pseudochrobactrum species examined so far. The polyamine pattern of $\mathrm{Sa}^{2} 5^{\mathrm{T}}$ consisted of the major compounds putrescine $\left[99.7 \mu \mathrm{mol}(\mathrm{g} \text { dry weight })^{-1}\right]$ and spermidine $\left.[12.1 \mu \mathrm{mol} \text { (g dry weight })^{-1}\right]$ and minor amounts of spermine $\left[1.8 \mu \mathrm{mol}(\mathrm{g} \text { dry weight })^{-1}\right]$. Pseudochrobactrum glaciei KMM $3858^{\mathrm{T}}$ exhibited a similar polyamine pattern, with the major compounds putrescine [56.7 $\mu \mathrm{mol}$ (g dry weight $\left.)^{-1}\right]$ and spermidine $\left[33.9 \mu \mathrm{mol}(\mathrm{g} \text { dry weight })^{-1}\right]$ and minor amounts of spermine $[0.4 \mu \mathrm{mol}$ (g dry weight $)^{-1}$. This polyamine pattern distinguishes the two strains from Pseudochrobactrum, Ochrobactrum and Brucella species, which have been reported to contain high putrescine concentrations, but the major compound is spermidine (Pseudochrobactrum) or sym-homospermidine is present (Ochrobactrum and Brucella) (Kämpfer et al., 2006, 2007a, b, 2008; Scholz et al., 2008). Table 1 summarizes the major chemotaxonomic features in comparison with those of the genera Pseudochrobactrum, Ochrobactrum and Brucella.

The results of fatty acid analysis are shown in Supplementary Table S1. Fatty acids were analysed according to Kämpfer \& Kroppenstedt (1996). The fatty acid profile of strain $\mathrm{Sa}_{2} 5^{\mathrm{T}}$ was composed mainly of $\mathrm{C}_{19: 0}$ cyclo $\omega 8 c(45.2 \%), \mathrm{C}_{18: 1} \omega 7 c(29.5 \%), \mathrm{C}_{18: 0}(4.0 \%)$ and $\mathrm{C}_{16: 0}(10.6 \%)$ and showed high similarity to the fatty acid profiles of the type strains of Pseudochrobactrum kiredjianiae and Pseudochrobactrum glaciei. There were no clear similarities to the fatty acid profiles of the type strains of

Table 1. Characteristics that differentiate the genera Paenochrobactrum gen. nov., Ochrobactrum, Pseudochrobactrum and Brucella

Genera: 1, Paenochrobactrum gen. nov.; 2, Ochrobactrum (data from Huber et al., 2010; Kämpfer et al., 2007b, 2008; B. Huber and H.-J. Busse, unpublished results); 3, Pseudochrobactrum (Kämpfer et al., 2006, 2007a, 2009); 4, Brucella (Scholz et al., 2008, 2010).

\begin{tabular}{|lccccc|}
\hline Characteristic & $\mathbf{1}$ & $\mathbf{2}$ & $\mathbf{3}$ & $\mathbf{4}$ \\
\hline Polyamine pattern & & & & & \\
sym-Homospermidine present & - & + & - & + \\
$\begin{array}{l}\text { Major compound } \\
\text { Polar lipid profile }\end{array}$ & $\mathrm{P}$ & $\mathrm{S}$ or S and P & $\mathrm{S}$ & $\mathrm{S}$ \\
Stretched aminolipid present & + & - & - & - \\
\hline
\end{tabular}

${ }^{\star} \mathrm{P}$, Putrescine; $\mathrm{s}$, spermidine. 
Pseudochrobactrum asaccharolyticum or Pseudochrobactrum saccharolyticum.

Results of the physiological characterization are given in the species description and in Table 2. Methods used were described previously (Kämpfer et al., 1991). The organism can be differentiated clearly from Pseudochrobactrum glaciei and the other Pseudochrobactrum species on the basis of several tests.

DNA-DNA hybridization experiments were performed with $\mathrm{Sa} 25^{\mathrm{T}}$ and Pseudochrobactrum glaciei $\mathrm{KMM} 3858^{\mathrm{T}}$ and

Table 2. Physiological characteristics of strain $\mathrm{Sa}^{2} 5^{\top}$, Paenochrobactrum glaciei comb. nov. KMM $3858^{\top}$ and type strains of Pseudochrobactrum species

Strains: $1, \mathrm{Sa}_{2} 5^{\mathrm{T}} ; 2$, Paenochrobactrum glaciei comb. nov. KMM $3858^{\mathrm{T}} ;$ 3, Pseudochrobactrum kiredjianiae CCUG $49584^{\mathrm{T}} ; \quad 4$, Pseudochrobactrum asaccharolyticum CCUG 46016 ${ }^{\mathrm{T}} ;$ 5, Pseudochrobactrum saccharolyticum CCUG $33853^{\mathrm{T}}$. Data were obtained in this study. + , Positive; -, negative; $(+)$, weakly positive. All strains were positive for hydrolysis of L-alanine $p$ nitroanilide (pNA) and L-proline pNA and weak hydrolysis of bis- $p$ nitrophenyl ( $\mathrm{pNP}$ ) phosphate. All strains were negative for hydrolysis of aesculin, $\mathrm{pNP} \beta$-D-galactopyranoside, $\mathrm{pNP} \beta$-D-glucuronide, $\mathrm{pNP}$ $\alpha$-D-glucopyranoside, pNP $\beta$-D-glucopyranoside, pNP phosphorylcholine, pNP phenylphosphonate and 2-deoxythymidine- $5^{\prime}$-pNP phosphate. All strains were also positive for assimilation of acetate and L-alanine. All strains were negative for assimilation of adonitol, $p$ arbutin, cellobiose, D-gluconate, myo-inositol, maltose, maltitol, Dmannitol, $\alpha$-melibiose, D-sorbitol, salicin, trehalose, putrescine, Lphenylalanine, L-tryptophan, 3-hydroxybenzoate, trans-aconitate, adipate, citrate, itaconate, mesaconate, L-leucine, phenylacetate, suberate, azelate and 4-hydroxybenzoate.

\begin{tabular}{|c|c|c|c|c|c|}
\hline Assimilation of: & 1 & 2 & 3 & 4 & 5 \\
\hline L-Arabinose & - & - & - & - & + \\
\hline D-Xylose & - & + & - & - & + \\
\hline D-Mannose & - & $(+)$ & - & - & + \\
\hline D-Glucose & + & $(+)$ & + & - & + \\
\hline D-Fructose & - & + & - & - & + \\
\hline DL-3-Hydroxybutyrate & - & - & - & - & + \\
\hline D-Galactose & - & + & $(+)$ & - & + \\
\hline Pyruvate, ornithine & - & - & - & - & + \\
\hline Propionate & + & - & + & - & + \\
\hline D-Ribose, glutarate & - & - & + & - & + \\
\hline Fumarate & - & - & + & - & + \\
\hline DL-Lactate & + & - & + & - & + \\
\hline L-Malate & - & - & + & - & + \\
\hline L-Rhamnose & - & - & + & - & - \\
\hline 4-Aminobutyrate, $\beta$-alanine & + & - & + & - & + \\
\hline cis-Aconitate & - & - & - & + & + \\
\hline$N$-Acetyl-D-glucosamine & - & + & $(+)$ & - & + \\
\hline L-Aspartate & - & - & $(+)$ & - & + \\
\hline L-Histidine & - & + & - & - & + \\
\hline
\end{tabular}

also with the type strains of three other Pseudochrobactrum species using the method described by Ziemke et al. (1998) except that, for nick translation, $2 \mu \mathrm{g}$ DNA was labelled during a $3 \mathrm{~h}$ incubation at $15{ }^{\circ} \mathrm{C}$. Strain Sa $25^{\mathrm{T}}$ showed moderate DNA-DNA relatedness to Pseudochrobactrum glaciei $\mathrm{KMM} 3858^{\mathrm{T}}(50.3 \%)$ and lower DNA-DNA relatedness to Pseudochrobactrum asaccharolyticum CCUG $46016^{\mathrm{T}} \quad(24.8 \%), \quad$ Pseudochrobactrum saccharolyticum CCUG $33852^{\mathrm{T}}(45.7 \%)$ and Pseudochrobactrum kiredjianiae CCUG $49584^{\mathrm{T}}(40.9 \%)$. Values given are means of two independent analyses.

From the results of $16 \mathrm{~S}$ rRNA gene and recA sequencing and from the physiological characteristics, it is evident that strain $\mathrm{Sa} 25^{\mathrm{T}}$ is different from Pseudochrobactrum asaccharolyticum, Pseudochrobactrum saccharolyticum and Pseudochrobactrum kirediianiae. Furthermore, strain Sa $25^{\mathrm{T}}$ shares with Pseudochrobactrum glaciei $\mathrm{KMM} 3858^{\mathrm{T}}$ a polyamine pattern and a polar lipid profile containing a stretched aminolipid that are unique among the Brucellaceae. For this reason, we propose the novel genus Paenochrobactrum gen. nov., with the type species Paenochrobactrum gallinarii sp. nov., and the reclassification of Pseudochrobactrum glaciei as a second species of this genus, Paenochrobactrum glaciei comb. nov.

\section{Description of Paenochrobactrum gen. nov.}

Paenochrobactrum (Pae'no.chro.bac'trum. L. adv. paene nearly, almost; N.L. neut. n. Ochrobactrum a bacterial genus name; N.L. masc. n. Paenochrobactrum almost Ochrobactrum).

Cells are non-motile, non-spore-forming rods (approx. $2 \mu \mathrm{m}$ long). Gram-negative and oxidase-positive, showing an oxidative metabolism. The polyamine pattern exhibits the major compound putrescine and moderate to large amounts of spermidine, while sym-homospermidine is absent. The polar lipids consist of the major compounds phosphatidylethanolamine, phosphatidylglycerol, diphosphatidylglycerol, phosphatidylcholine, phosphatidylmonomethylethanolamine and unknown aminolipid AL1 and moderate or minor amounts of unknown polar lipids L1 and L2. In addition, an aminolipid that stretches over a long range in the first chromatographic dimension (stretched aminolipid) is detectable (Supplementary Fig. S2). The quinone system is ubiquinone Q-10. Major fatty acids are $\mathrm{C}_{18: 1} \omega 7 c$ and $\mathrm{C}_{19: 0}$ cyclo $\omega 8 c$. On the basis of $16 \mathrm{~S}$ rRNA gene sequence analysis, most closely related to the genera Pseudochrobactrum, Ochrobactrum and Brucella. Member of the family Brucellaceae. The type species is Paenochrobactrum gallinarii.

\section{Description of Paenochrobactrum gallinarii sp. nov.}

Paenochrobactrum gallinarii (gal.li.na'ri.i. L. n. gallinarium a coop; L. gen. n. gallinarii of a coop, referring to the isolation of the type strain from a duck barn). 
Shares all characteristics listed in the genus description. Good growth occurs on R2A agar, TSA, nutrient agar and MacConkey agar at $25-30{ }^{\circ} \mathrm{C}$. Beige, translucent and shiny colonies with entire edges form within $24 \mathrm{~h}$, with a diameter of approximately $2 \mathrm{~mm}$. Carbon source utilization and hydrolysis of chromogenic substrates (including differentiating characters for all Paenochrobactrum and Pseudochrobactrum species) are indicated in Table 2. In addition to the lipids listed in the genus description, moderate amounts of the polar lipid L3, unknown aminolipid AL2 and unknown aminophospholipid APL2 are present, and other lipids are present in minor to trace amounts. Quinone system and polyamine pattern are as listed in the genus description. In addition, the polyamine pattern contains small amounts of spermine. The G+C content of the DNA of the type strain is $49.7 \mathrm{~mol} \%$.

The type strain is Sa $25^{\mathrm{T}}\left(=\mathrm{CCUG} 57736^{\mathrm{T}}=\mathrm{CCM} 7656^{\mathrm{T}}\right)$, isolated from a duck barn in Germany.

\section{Description of Paenochrobactrum glaciei comb. nov.}

Basonym: Pseudochrobactrum glaciei Romanenko et al. 2008.

The description of the species is that given in the description of Pseudochrobactrum glaciei provided by Romanenko et al. (2008) with the following additions. The polar lipid profile exhibits the characteristics listed in the genus description. Furthermore, the polar lipid profile contains an unidentified aminolipid, which exhibits the same $R_{\mathrm{f}}$ as AL1 in the second dimension but a slightly lower $R_{\mathrm{f}}$ in the first dimension. The quinone system and polyamine pattern are as listed in the genus description. In addition, the polyamine pattern contains small amounts of 1,3-diaminopropane and spermine.

The type strain is $2126^{\mathrm{T}}\left(=\mathrm{KMM} 3858^{\mathrm{T}}=\right.$ NRIC $0733^{\mathrm{T}}$ $=\mathrm{JCM} 15115^{\mathrm{T}}$ ).

\section{Acknowledgements}

We thank Dr I. Romanenko for kindly providing the type strain of Pseudochrobactrum glaciei, KMM $3858^{\mathrm{T}}$.

\section{References}

Altenburger, P., Kämpfer, P., Makristathis, A., Lubitz, W. \& Busse, H.-J. (1996). Classification of bacteria isolated from a medieval wall painting. J Biotechnol 47, 39-52.

Busse, H.-J. \& Auling, G. (1988). Polyamine pattern as a chemotaxonomic marker within the Proteobacteria. Syst Appl Microbiol 11, 1-8.

Busse, H.-J., Bunka, S., Hensel, A. \& Lubitz, W. (1997). Discrimination of members of the family Pasteurellaceae based on polyamine patterns. Int J Syst Bacteriol 47, 698-708.

Cashion, P., Holder-Franklin, M. A., McCully, J. \& Franklin, M. (1977). A rapid method for the base ratio determination of bacterial DNA. Anal Biochem 81, 461-466.
Gerhardt, P., Murray, R. G. E., Wood, W. A. \& Krieg, N. R. (editors) (1994). Methods for General and Molecular Bacteriology. Washington, DC: American Society for Microbiology.

Huber, B., Scholz, H. C., Kämpfer, P., Falsen, E., Langer, S. \& Busse, H.-J. (2010). Ochrobactrum pituitosum sp. nov., isolated from an industrial environment. Int J Syst Evol Microbiol 60, 321326.

Kämpfer, P. \& Kroppenstedt, R. M. (1996). Numerical analysis of fatty acid patterns of coryneform bacteria and related taxa. Can J Microbiol 42, 989-1005.

Kämpfer, P., Steiof, M. \& Dott, W. (1991). Microbiological characterization of a fuel-oil contaminated site including numerical identification of heterotrophic water and soil bacteria. Microb Ecol 21, 227-251.

Kämpfer, P., Dreyer, U., Neef, A., Dott, W. \& Busse, H.-J. (2003). Chryseobacterium defluvii sp. nov., isolated from wastewater. Int J Syst Evol Microbiol 53, 93-97.

Kämpfer, P., Rosselló-Mora, R., Scholz, H., Welinder-Olsen, C. \& Busse, H.-J. (2006). Description of Pseudochrobactrum gen. nov., with the two species Pseudochrobactrum asaccharolyticum sp. nov. and Pseudochrobactrum saccharolyticum sp. nov. Int J Syst Evol Microbiol 56, 1823-1829.

Kämpfer, P., Scholz, H., Huber, B., Thummes, K., Busse, H.-J., Maas, E. W. \& Falsen, E. (2007a). Description of Pseudochrobactrum kiredjianiae sp. nov. Int J Syst Evol Microbiol 57, 755-760.

Kämpfer, P., Scholz, H. C., Falsen, E. \& Busse, H.-J. (2007b). Ochrobactrum haematophilum sp. nov. and Ochrobactrum pseudogrignonense sp. nov., isolated from human clinical specimens. Int $J$ Syst Evol Microbiol 57, 2513-2518.

Kämpfer, P., Sessitsch, A., Schloter, M., Huber, B., Busse, H.-J. \& Scholz, H. C. (2008). Ochrobactrum rhizosphaerae sp. nov. and Ochrobactrum thiophenivorans sp. nov., isolated from the environment. Int J Syst Evol Microbiol 58, 1426-1431.

Kämpfer, P., Huber, B., Lodders, N., Warfolomeow, l., Busse, H.-J. \& Scholz, H. C. (2009). Pseudochrobactrum lubricantis sp. nov., isolated from a metal-working fluid. Int J Syst Evol Microbiol 59, 24642467.

Lane, D. J. (1991). 16S/23S rRNA sequencing. In Nucleic Acid Techniques in Bacterial Systematics, pp. 115-175. Edited by E. Stackebrandt \& M. Goodfellow. Chichester: Wiley.

Ludwig, W., Strunk, O., Westram, R., Richter, L., Meier, H., Yadhukumar, Buchner, A., Lai, T., Steppi, S. \& other authors (2004). ARB: a software environment for sequence data. Nucleic Acids Res 32, 1363-1371.

Mesbah, M., Premachandran, U. \& Whitman, W. B. (1989). Precise measurement of the $\mathrm{G}+\mathrm{C}$ content of deoxyribonucleic acid by highperformance liquid chromatography. Int J Syst Bacteriol 39, 159-167.

Olsen, G. J., Matsuda, H., Hagström, R. \& Overbeek, R. (1994). fastDNAml: a tool for construction of phylogenetic trees of DNA sequences using maximum likelihood. Comput Appl Biosci 10, 41-48.

Pruesse, E., Quast, C., Knittel, K., Fuchs, B. M., Ludwig, W., Peplies, J. \& Glöckner, F. O. (2007). SILVA: a comprehensive online resource for quality checked and aligned ribosomal RNA sequence data compatible with ARB. Nucleic Acids Res 35, 7188-7196.

Romanenko, L. A., Tanaka, N., Frolova, G. M. \& Mikhailov, V. V. (2008). Pseudochrobactrum glaciei sp. nov., isolated from sea ice collected from Peter the Great Bay of the Sea of Japan. Int J Syst Evol Microbiol 58, 2454-2458.

Scholz, H. C., Tomaso, H., Al Dahouk, S., Witte, A., Schloter, M., Kämpfer, P., Falsen, E. \& Neubauer, H. (2006). Genotyping of Ochrobactrum anthropi by recA-based comparative sequence, 
PCR-RFLP, and 16S rRNA gene analysis. FEMS Microbiol Lett 257, 7-16.

Scholz, H. C., Hubalek, Z., Sedláček, I., Vergnaud, G., Tomaso, H., Al Dahouk, S., Melzer, F., Kämpfer, P., Neubauer, H. \& other authors (2008). Brucella microti sp. nov., isolated from the common vole Microtus arvalis. Int J Syst Evol Microbiol 58, 375-382.

Scholz, H. C., Nöckler, K., Göllner, C., Bahn, P., Vergnaud, G., Tomaso, H., Al Dahouk, S., Kämpfer, P., Cloeckaert, A. \& other authors (2010). Brucella inopinata sp. nov., isolated from a breast implant infection. Int J Syst Evol Microbiol 60, 801-808.

Stolz, A., Busse, H.-J. \& Kämpfer, P. (2007). Pseudomonas knackmussii sp. nov. Int J Syst Evol Microbiol 57, 572-576.
Tamura, K., Dudley, J., Nei, M. \& Kumar, S. (2007). MEGA4: molecular evolutionary genetics analysis (MEGA) software version 4.0. Mol Biol Evol 24, 1596-1599.

Tindall, B. J. (1990a). Lipid composition of Halobacterium lacusprofundi. FEMS Microbiol Lett 66, 199-202.

Tindall, B. J. (1990b). A comparative study of the lipid composition of Halobacterium saccharovorum from various sources. Syst Appl Microbiol 13, 128-130.

Ziemke, F., Höfle, M. G., Lalucat, J. \& Rosselló-Mora, R. (1998). Reclassification of Shewanella putrefaciens Owen's genomic group II as Shewanella baltica sp. nov. Int J Syst Bacteriol 48, 179186. 